\title{
The Promising Role of Mushrooms as a Therapeutic Adjuvant of Conventional Cancer Therapies
}

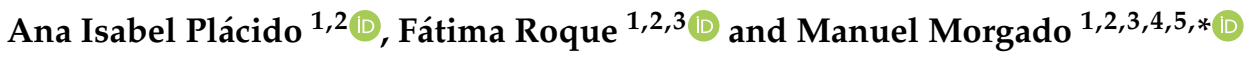 \\ 1 Health Sciences School, Polytechnic of Guarda, Rua da Cadeia, 6300-035 Guarda, Portugal; \\ anaplacido@ipg.pt (A.I.P.); froque@ipg.pt (F.R.) \\ 2 Research Unit for Inland Development, Polytechnic of Guarda (UDI-IPG), Av. Dr. Francisco Sá Carneiro 50, \\ 6300-559 Guarda, Portugal \\ 3 CICS-UBI-Health Sciences Research Centre, University of Beira Interior, Av. Infante D. Henrique, \\ 6200-506 Covilhã, Portugal \\ 4 Health Sciences Faculty, University of Beira Interior, Av. Infante D. Henrique, 6200-506 Covilhã, Portugal \\ 5 Pharmaceutical Services of University Hospital Centre of Cova da Beira, Quinta do Alvito, \\ 6200-251 Covilhã, Portugal \\ * Correspondence: mmorgado@ipg.pt
}

check for updates

Citation: Plácido, A.I.; Roque, F.; Morgado, M. The Promising Role of Mushrooms as a Therapeutic Adjuvant of Conventional Cancer Therapies. Biologics 2022, 2, 58-68 https://doi.org/10.3390/ biologics2010005

Academic Editor: João C Fernandes

Received: 8 January 2022

Accepted: 27 January 2022

Published: 29 January 2022

Publisher's Note: MDPI stays neutral with regard to jurisdictional claims in published maps and institutional affiliations.

Copyright: (C) 2022 by the authors. Licensee MDPI, Basel, Switzerland. This article is an open access article distributed under the terms and conditions of the Creative Commons Attribution (CC BY) license (https:// creativecommons.org/licenses/by/ $4.0 /)$.

\begin{abstract}
Complementary and alternative medicine (CAM) has been fronted as an alternative due to its potential for holistic treatment. Many CAMs are plant-derived, including algae and mushrooms that have been used widely in many parts of the world, where they are regarded as biological response modifiers. The purpose of this article was to review the role of mushrooms as an adjuvant in conventional therapies, to reveal the therapeutic substances of mushrooms as an adjuvant in conventional therapies, to bring together the available scientific data on the medical effects of mushrooms in oncology, and verify its efficacy and safety. A literature search was conducted in September 2021 on the MEDLINE-PubMed and Cochrane databases to identify relevant randomized controlled trials or clinical trials studies addressing the use of whole mushroom formulations as complementary therapy during conventional cancer treatment.: The findings from the present study suggest that mushrooms may act as a potentiator of host defense mechanisms and decrease adverse events for patients with cancer undergoing conventional therapies. New protocols to conduct clinical trials are needed to elucidate the possible active mechanisms and clinical benefits of these fungi in various types of cancer.
\end{abstract}

Keywords: adjuvant; cancer; conventional therapy; mushroom

\section{Introduction}

Cancer incidence and mortality are increasing worldwide. According to the World Health Organization (WHO), cancer is a leading cause of death [1,2]. Conventional therapies such as chemotherapy, radiotherapy, and immunotherapy are associated with secondary side effects including gastrointestinal symptoms or immunosuppression that compromise the quality of life of patients [3,4]. In this context, complementary alternative medicine (CAM) has gained consensus opinions as an alternative and/or complementary treatment [5,6]. Many CAMs take advantage of the ability of mushrooms to act as biological modifiers [3].

In vitro studies demonstrated that compounds isolated from mushrooms can modulate several biochemical pathways, including antioxidant [7], anti-inflammatory [8], and antimicrobial responses [9]. Mushroom bioactive compounds have also been associated with the modulation of apoptosis, cell proliferation, and angiogenesis [10].

The promising effects of mushrooms have been demonstrated on mushroom isolated compounds, and the role of the entire mushroom substances has been underestimated. Considering that it has been suggested that all active compounds of mushrooms can act 
synergistically in cancer cell signaling pathways [11] and that mushroom active compounds combined with conventional therapies [11] can improve the outcome of and tolerance to invasive treatments [12-14], this work aims to provide an overview of the role of mushrooms as an adjuvant in conventional therapies, that emerged in clinical studies.

\section{Results}

The search of the databases yielded 161 citations (Figure 1). After screening titles and abstracts, seven articles potentially met the inclusion criteria and were fully screened. From the full screening analyses six new articles were retrieved. Within the 13 articles that potentially met the inclusion criteria, 3 were excluded because they did not evaluate the synergistic effect of mushrooms $(n=2)$ or were performed in a cell line model $(n=1)$. Eleven articles [5,15-24] fully satisfied the inclusion criteria and were included in this review.

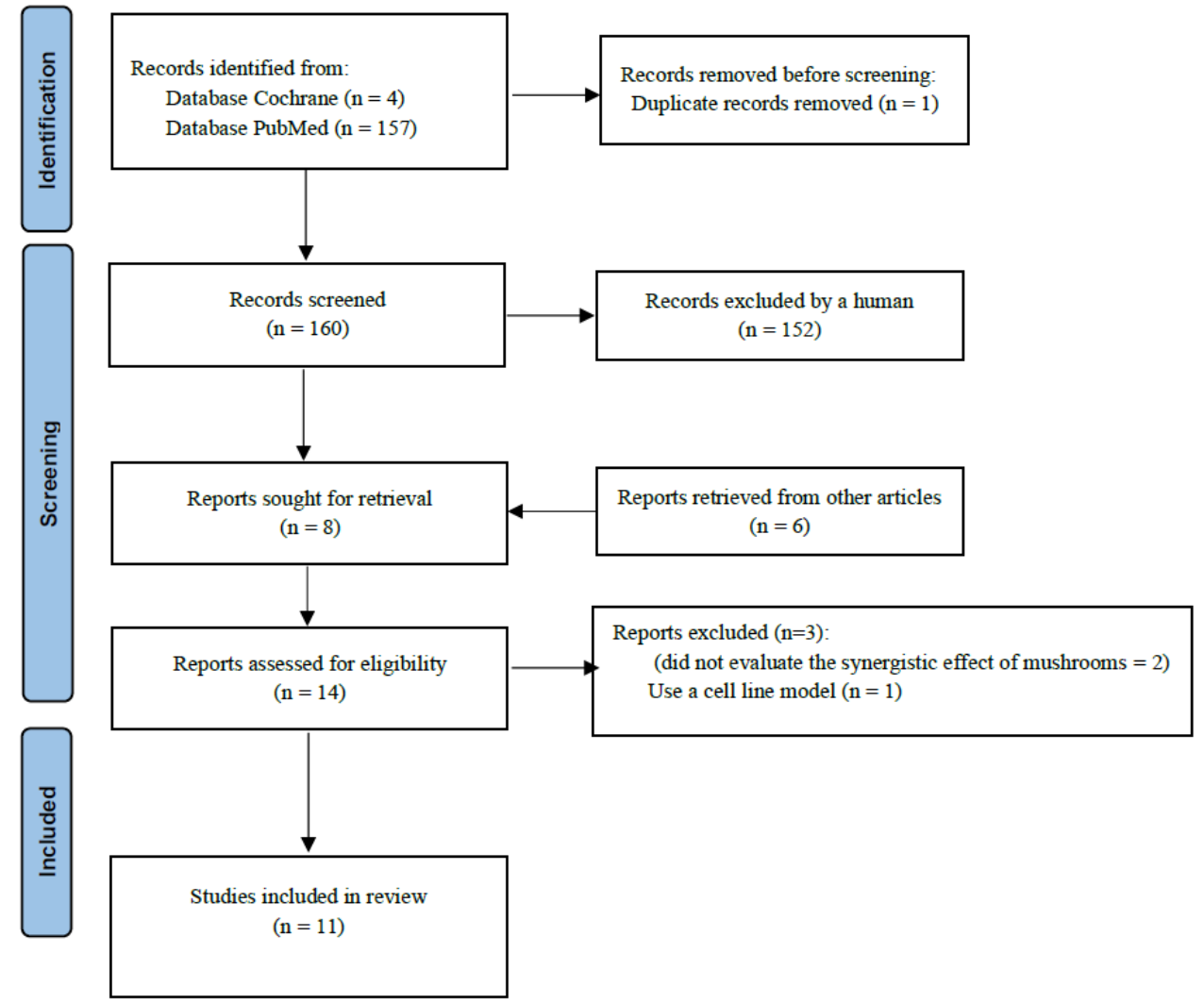

Figure 1. PRISMA diagram of the literature selection in this narrative review.

\subsection{Characteristics of the Included Studies}

A description of the characteristics of the included studies is presented in Table 1. Among the included studies, four were conducted in Japan [18,19,21,23], two in Brazil [20,22], one in Singapore [15], one in Taiwan [16], one in China [5], one in South Korea [24] and one in Norway [17].

Regarding the study design, five articles were clinical trials $[15-17,20,24]$, open label trials $(n=2)[18,19]$, single-group open studies $(n=2)[21,23]$ or randomized controlled trials [5,22]. 
Table 1. Characteristics of the included studies.

\begin{tabular}{|c|c|c|c|c|c|c|c|c|c|c|}
\hline Author (Year) & Country & Species Name & Type of Study & Sample Size & Cancer Type & $\begin{array}{l}\text { Conventional } \\
\text { Therapy (CT) }\end{array}$ & Treatment (T) & $\begin{array}{c}\text { Duration of } \\
\text { Treatment }\end{array}$ & Outcomes Measures & $\begin{array}{l}\text { Significant } \\
\text { Findings }\end{array}$ \\
\hline $\begin{array}{l}\text { Chay et al. } \\
\text { (2017) } \\
\text { [15] }\end{array}$ & Singapore & Coriolus versicolor & Clinical trial & $\begin{array}{l}\text { CT: } 6 \\
\text { T: } 9\end{array}$ & $\begin{array}{l}\text { Advanced } \\
\text { hepatocellular } \\
\text { carcinoma }\end{array}$ & Placebo & $\begin{array}{l}\text { Standard } \\
\text { continuous daily } \\
\text { dose of } 2.4 \mathrm{~g}\end{array}$ & $\begin{array}{l}\text { CT: } 1.5 \text { cycles } \\
\text { (5.9 weeks) } \\
\text { T: } 3 \text { cycles } \\
(12.1 \text { weeks })\end{array}$ & $\begin{array}{l}\text { Primary outcomes: median } \\
\text { time to progression. } \\
\text { Secondary outcomes: } \\
\text { response rates, toxicity, } \\
\text { quality of life, } \\
\text { progression-free survival, } \\
\text { and overall survival. }\end{array}$ & $\begin{array}{l}\text { Better social and } \\
\text { emotional } \\
\text { functioning scores. } \\
\text { Better appetite. } \\
\text { Less pain } \\
\text { symptoms. }\end{array}$ \\
\hline $\begin{array}{c}\text { Tsai et al. (2016) } \\
\text { [16] }\end{array}$ & Taiwan & $\begin{array}{c}\text { Antrodia } \\
\text { cinnamomea (AC) }\end{array}$ & $\begin{array}{l}\text { Randomized } \\
\text { clinical trial }\end{array}$ & $\begin{array}{l}\text { CT: } 20 \\
\text { T: } 17\end{array}$ & $\begin{array}{l}\text { Advanced or } \\
\text { recurrent, } \\
\text { untreated, stage } \\
\text { III-IV } \\
\text { adenocarcinomas }\end{array}$ & $\begin{array}{l}\text { Chemotherapy + } \\
\text { placebo }\end{array}$ & $\begin{array}{l}\text { Chemotherapy + } \\
\text { A. cinnamomea } \\
\text { (orally, } 20 \mathrm{~mL} \\
\text { twice daily) }\end{array}$ & 30 days & $\begin{array}{l}\text { Primary outcomes: 6-month } \\
\text { overall survival. } \\
\text { Secondary outcomes: disease } \\
\text { control rate, quality of life, } \\
\text { adverse event, and } \\
\text { biochemical features. }\end{array}$ & $\begin{array}{l}\text { Improvements in } \\
\text { quality of sleep. }\end{array}$ \\
\hline $\begin{array}{l}\text { Tangen et al. } \\
\text { (2015) } \\
{[17]}\end{array}$ & Norway & $\begin{array}{l}82.4 \% \text { of Agaricus } \\
\text { blazei Murill, } 14.7 \% \\
\text { of Hericium } \\
\text { erinaceus, and } 2.9 \% \\
\text { of Grifola frondosa } \\
\text { (AndoSan) }\end{array}$ & $\begin{array}{l}\text { Randomized } \\
\text { clinical trial }\end{array}$ & $\begin{array}{l}\text { CT: } 21 \\
\text { T: } 19\end{array}$ & Multiple myeloma & $\begin{array}{l}\text { Chemotherapy } \\
\text { with autologous } \\
\text { stem cell support + } \\
\text { placebo }\end{array}$ & $\begin{array}{c}\text { Chemotherapy } \\
\text { with autologous } \\
\text { stem cell support } \\
\text { + AndoSan } \\
\text { (60 mL daily } \\
\text { orally) }\end{array}$ & 7 weeks & $\begin{array}{l}\text { Primary outcomes: serum } \\
\text { levels of cytokines, } \\
\text { chemokines, and growth } \\
\text { factors; expression levels of } \\
\text { genes involved in immune } \\
\text { activation by whole genome } \\
\text { assay; stem cell harvest } \\
\text { product of several } \\
\text { mononuclear cell subsets } \\
\text { associated with the immune } \\
\text { system. } \\
\text { Primary outcomes: overall } \\
\text { survival, quality of life. }\end{array}$ & $\begin{array}{c}\text { Increase in serum } \\
\text { levels of IL-1, IL-5 } \\
\text { and IL-7. } \\
\text { Increased } \\
\text { expression of } \\
\text { immunoglobulin } \\
\text { genes, killer } \\
\text { immunoglobulin } \\
\text { receptor genes } \\
\text { and HLA genes. }\end{array}$ \\
\hline $\begin{array}{c}\text { Nagashima et al. } \\
(2013) \\
{[18]}\end{array}$ & Japan & $\begin{array}{l}\text { Lentinula edodes } \\
\text { (LEM) }\end{array}$ & $\begin{array}{l}\text { Open-label trial } \\
\text { with a single } \\
\text { group }\end{array}$ & 10 & Breast cancer & $\begin{array}{l}\text { Chemotherapy } \\
\text { alone ( } 3 \text { weeks) }\end{array}$ & $\begin{array}{l}\text { LEM (1800 } \\
\text { mg/day) + } \\
\text { chemotherapy } \\
(3 \text { weeks })\end{array}$ & $\begin{array}{c}6 \text { weeks } \\
\text { (3 weeks each) }\end{array}$ & $\begin{array}{l}\text { Primary outcomes: quality of } \\
\text { life and immune function. }\end{array}$ & Not achieved. \\
\hline $\begin{array}{l}\text { Suzuki et al. } \\
\quad \text { (2013) } \\
\text { [19] }\end{array}$ & Japan & $\begin{array}{l}\text { Lentinula edodes } \\
\text { (LEM) }\end{array}$ & $\begin{array}{c}\text { Single-arm, } \\
\text { open-label study }\end{array}$ & 20 & Breast cancer & $\begin{array}{l}\text { Hormone therapy } \\
\text { (4 weeks) }\end{array}$ & $\begin{array}{c}\text { Hormone } \\
\text { therapy + LEM } \\
\text { (oral ingestion at } \\
1800 \text { mg daily) } \\
\text { (8 weeks) }\end{array}$ & 12 weeks & $\begin{array}{l}\text { Primary outcomes: quality of } \\
\text { life and peripheral blood } \\
\text { cytokine production levels. }\end{array}$ & Not achieved. \\
\hline $\begin{array}{l}\text { Valadares et al. } \\
\qquad(2013) \\
{[20]}\end{array}$ & Brazil & Agaricus sylvaticus & $\begin{array}{l}\text { Randomized } \\
\text { clinical trial }\end{array}$ & $\begin{array}{l}\text { CT: } 23 \\
\text { T: } 23\end{array}$ & Breast cancer & $\begin{array}{l}\text { Chemotherapy + } \\
\text { placebo }\end{array}$ & $\begin{array}{c}\text { Chemotherapy + } \\
\text { A. sylvaticus } \\
(2.1 \mathrm{~g} \text {, in two } \\
\text { daily } \\
\text { administrations) }\end{array}$ & $\begin{array}{c}\text { 3-6 months } \\
\text { (21 days cycles) }\end{array}$ & $\begin{array}{l}\text { Primary outcomes: adverse } \\
\text { events. }\end{array}$ & $\begin{array}{c}\text { Improved } \\
\text { nutritional status } \\
\text { and reduced } \\
\text { abnormal bowel } \\
\text { functions, nausea, } \\
\text { vomiting, and } \\
\text { anorexia. }\end{array}$ \\
\hline
\end{tabular}


Table 1. Cont.

\begin{tabular}{|c|c|c|c|c|c|c|c|c|c|c|}
\hline Author (Year) & Country & Species Name & Type of Study & Sample Size & Cancer Type & $\begin{array}{l}\text { Conventional } \\
\text { Therapy (CT) }\end{array}$ & Treatment (T) & $\begin{array}{c}\text { Duration of } \\
\text { Treatment }\end{array}$ & Outcomes Measures & $\begin{array}{l}\text { Significant } \\
\text { Findings }\end{array}$ \\
\hline $\begin{array}{l}\text { Zhao et al. } \\
\text { (2012) } \\
{[5]}\end{array}$ & China & Ganoderma lucidum & $\begin{array}{l}\text { Randomized } \\
\text { controlled trial }\end{array}$ & $\begin{array}{l}\text { CT: } 23 \\
\text { T: } 25\end{array}$ & Breast cancer & Placebo & $\begin{array}{l}\text { Spore powder of } \\
\text { G. lucidum } \\
\text { (1000 mg } 3 \text { times } \\
\text { a day) }\end{array}$ & 4 weeks & $\begin{array}{c}\text { Primary outcomes: } \\
\text { functional assessment of } \\
\text { cancer therapy-fatigue } \\
\text { (FACT-F), hospital anxiety } \\
\text { and depression scale } \\
\text { (HADS), EORTC quality-of } \\
\text { life questionnaires } \\
\text { (QLQ-C30). } \\
\text { Secondary outcomes: TNF- } \alpha \text {, } \\
\text { IL-6, and liver-kidney } \\
\text { function. }\end{array}$ & $\begin{array}{c}\text { Beneficial effects } \\
\text { on cancer-related } \\
\text { fatigue and } \\
\text { quality of life in } \\
\text { breast cancer } \\
\text { patients } \\
\text { undergoing } \\
\text { endocrine therapy. }\end{array}$ \\
\hline $\begin{array}{l}\text { Okuno and Uno } \\
\text { (2011) } \\
{[21]}\end{array}$ & Japan & $\begin{array}{l}\text { Lentinula edodes } \\
\text { (LEM) }\end{array}$ & $\begin{array}{l}\text { Single-group } \\
\text { open study }\end{array}$ & 8 & $\begin{array}{l}\text { Gastric and } \\
\text { colorectal cancer }\end{array}$ & $\begin{array}{l}\text { Chemotherapy } \\
\text { alone (4 weeks) }\end{array}$ & $\begin{array}{c}\text { Chemotherapy + } \\
\text { LEM } \\
(1800 \mathrm{mg} / \text { day }) \\
\text { (4 weeks) }\end{array}$ & $\begin{array}{c}8 \text { weeks } \\
\text { (4 weeks each) }\end{array}$ & $\begin{array}{c}\text { Primary outcomes: adverse } \\
\text { events and IFN- } \gamma \\
\text { production by CD4 } 4^{+} \mathrm{T}, \mathrm{CD} 8^{+} \\
\mathrm{T} \text { and } \mathrm{CD} 56^{+} \mathrm{NK} / \mathrm{NKT} \text { cells. }\end{array}$ & $\begin{array}{l}\text { Decrease in the } \\
\text { incidence of } \\
\text { adverse effects. }\end{array}$ \\
\hline $\begin{array}{l}\text { Valadares et al. } \\
\text { (2011) } \\
{[22]}\end{array}$ & Brazil & Agaricus sylvaticus & $\begin{array}{l}\text { Randomized } \\
\text { controlled trial }\end{array}$ & $\begin{array}{l}\text { CT: } 23 \\
\text { T: } 23\end{array}$ & Breast cancer & $\begin{array}{c}\text { Chemotherapy + } \\
\text { placebo }\end{array}$ & $\begin{array}{c}\text { Chemotherapy }+ \\
\text { A. sylvaticus } \\
(2.1 \mathrm{~g} / \text { day })\end{array}$ & 6 months & $\begin{array}{l}\text { Primary outcomes: } \\
\text { hematological and } \\
\text { immunological parameters. }\end{array}$ & $\begin{array}{c}\text { Increase of } \\
\text { hematocrit, red } \\
\text { blood count, } \\
\text { MCHC, } \\
\text { leukocytes, } \\
\text { monocytes, and } \\
\text { total lymphocyte } \\
\text { count. }\end{array}$ \\
\hline $\begin{array}{c}\text { Ahn et al. (2004) } \\
\text { [24] }\end{array}$ & South Korea & $\begin{array}{l}\text { Agaricus blazei } \\
\text { Murill Kyowa } \\
\text { (ABMK) }\end{array}$ & $\begin{array}{l}\text { Randomized } \\
\text { clinical trial }\end{array}$ & $\begin{array}{l}\text { CT: } 61 \\
\text { T: } 39\end{array}$ & $\begin{array}{l}\text { Gynecological } \\
\text { cancer (cervical, } \\
\text { ovarian and } \\
\text { endometrial) }\end{array}$ & $\begin{array}{c}\text { Chemotherapy + } \\
\text { placebo }\end{array}$ & $\begin{array}{l}\text { Chemotherapy }+ \\
\text { ABMK (daily oral } \\
\text { consumption) }\end{array}$ & $\begin{array}{l}3 \text { weeks for at } \\
\text { least three cycles }\end{array}$ & $\begin{array}{l}\text { Primary outcomes: activities } \\
\text { of NK and LAK cells and the } \\
\text { counts of white blood cells, } \\
\text { lymphocytes, monocytes, } \\
\text { CD3p, CD4p, CD8p, CD48p, } \\
\text { and CD56p cells. }\end{array}$ & $\begin{array}{l}\text { ABMK treatment } \\
\text { might be } \\
\text { beneficial for } \\
\text { gynecological } \\
\text { cancer patients } \\
\text { undergoing } \\
\text { chemotherapy. }\end{array}$ \\
\hline
\end{tabular}

ABMK—Agaricus blazei Murill Kyowa; CT—conventional therapy; HLA—human leukocyte antigen; IAP—immunosuppressive acidic protein; IFN—interferon; LAK—lymphokine-

activated killer; LEM—Lentinula edodes mycelia extract; $\mathrm{MCHC}$ - mean corpuscular hemoglobin concentration; NK—natural killer; $\mathrm{T}$ - treatment. 
The participants of the included studies had breast cancer [5,18-20,22,23], hepatocellular carcinoma [15], advanced or recurrent, untreated, stage III-IV adenocarcinomas [16], multiple myeloma [17], gastric and colorectal cancer [21,23], and gynecological cancer [24]. The species of mushrooms used in the different studies were Lentinula eododes $[18,19,21,23]$, Agaricus sylvaticus [20,22], Agaricus blazei [17,24], Coriolus versicolor [15], Antrodia cinnamomea [16], and Ganoderma lucidum [5]. All mushrooms were administered orally. The dosage used varied according to mushroom species administered. In all studies that used Lentinula eododes the dosage administered was $1800 \mathrm{mg} /$ per day $[18,19,21,23]$. The Agaricus sylvaticus was administered with a dosage of $2.1 \mathrm{~g} /$ per day $[20,22]$.

\subsection{Quality of Included Studies}

The quality assessment result of each study is reported in Tables 2 and 3. Only two studies fulfilled more than $80 \%$ of the exploratory questions $[17,20]$ (Tables 2 and 3). Seven studies pointed out potential sources of bias $[5,15-18,21,23]$. The main limitations were related to the low sample size, lack of similarity of participants at baseline that could affect outcomes, and the lack of blindness to the participants' exposures.

Table 2. Quality Assessment of Controlled Intervention Studies through National Heart, Lung, and Blood Institute (NHLBI) quality assessment tool.

\begin{tabular}{|c|c|c|c|c|}
\hline \multicolumn{5}{|c|}{ Quality Assessment of Controlled Intervention Studies } \\
\hline \multirow{2}{*}{ No } & \multirow{2}{*}{ Question } & \multicolumn{3}{|c|}{ Number of Studies $(n=7)$} \\
\hline & & Yes & No & Other (CD, NA, NR) \\
\hline 1 & $\begin{array}{l}\text { Was the study described as randomized, a randomized trial, a randomized clinical trial, } \\
\text { or an RCT? }\end{array}$ & 7 & 0 & 0 \\
\hline 2 & Was the method of randomization adequate (i.e., use of randomly generated assignment)? & 2 & 0 & 5 \\
\hline 3 & Was the treatment allocation concealed (so that assignments could not be predicted)? & 2 & 0 & 5 \\
\hline 4 & Were study participants and providers blinded to treatment group assignment? & 4 & 0 & 3 \\
\hline 5 & Were the people assessing the outcomes blinded to the participants' group assignments? & 4 & 0 & 3 \\
\hline 6 & $\begin{array}{l}\text { Were the groups similar at baseline on important characteristics that could affect outcomes (e.g., } \\
\text { demographics, risk factors, co-morbid conditions)? }\end{array}$ & 1 & 3 & 3 \\
\hline 7 & $\begin{array}{l}\text { Was the overall drop-out rate from the study at endpoint } 20 \% \text { or lower of the number allocated } \\
\text { to treatment? }\end{array}$ & 6 & 1 & 0 \\
\hline 8 & $\begin{array}{l}\text { Was the differential drop-out rate (between treatment groups) at endpoint } 15 \text { percentage points } \\
\text { or lower? }\end{array}$ & 6 & 1 & 0 \\
\hline 9 & Was there high adherence to the intervention protocols for each treatment group? & 7 & 0 & 0 \\
\hline 10 & Were other interventions avoided or similar in the groups (e.g., similar background treatments)? & 6 & 1 & 0 \\
\hline 11 & $\begin{array}{c}\text { Were outcomes assessed using valid and reliable measures, implemented consistently across all } \\
\text { study participants? }\end{array}$ & 7 & 0 & 0 \\
\hline 12 & $\begin{array}{l}\text { Did the authors report that the sample size was sufficiently large to be able to detect a difference } \\
\text { in the main outcome between groups with at least } 80 \% \text { power? }\end{array}$ & 1 & 6 & 0 \\
\hline 13 & $\begin{array}{l}\text { Were outcomes reported or subgroups analyzed prespecified (i.e., identified before analyses } \\
\text { were conducted)? }\end{array}$ & 2 & 0 & 5 \\
\hline 14 & $\begin{array}{l}\text { Were all randomized participants analyzed in the group to which they were originally assigned, } \\
\text { i.e., did they use an intention-to-treat analysis? }\end{array}$ & 1 & 0 & 6 \\
\hline
\end{tabular}


Table 3. Quality Assessment of Before-After (Pre-Post) Studies with No Control Group Studies through National Heart, Lung, and Blood Institute (NHLBI) quality assessment tool.

\begin{tabular}{|c|c|c|c|c|}
\hline \multicolumn{5}{|c|}{ Quality Assessment Tool for Before-After (Pre-Post) Studies with No Control Group } \\
\hline \multirow{2}{*}{ No } & \multirow{2}{*}{ Question } & \multicolumn{3}{|c|}{ Number of Studies $(n=4)$} \\
\hline & & Yes & No & Other (CD, NA, NR) \\
\hline 1 & Was the study question or objective clearly stated? & 3 & 1 & 0 \\
\hline 2 & $\begin{array}{l}\text { Were eligibility/selection criteria for the study population prespecified and } \\
\text { clearly described? }\end{array}$ & 4 & 0 & 0 \\
\hline 3 & $\begin{array}{l}\text { Were the participants in the study representative of those who would be eligible for the } \\
\text { test/service/intervention in the general or clinical population of interest? }\end{array}$ & 0 & 4 & 0 \\
\hline 4 & Were all eligible participants that met the prespecified entry criteria enrolled? & 4 & 0 & 0 \\
\hline 5 & Was the sample size sufficiently large to provide confidence in the findings? & 0 & 4 & 0 \\
\hline 6 & $\begin{array}{l}\text { Was the test/service/intervention clearly described and delivered consistently across the study } \\
\text { population? }\end{array}$ & 4 & 0 & 0 \\
\hline 7 & $\begin{array}{l}\text { Were the outcome measures prespecified, clearly defined, valid, reliable, and assessed consistently } \\
\text { across all study participants? }\end{array}$ & 4 & 0 & 0 \\
\hline 8 & Were the people assessing the outcomes blinded to the participants' exposures/interventions? & 0 & 0 & 4 \\
\hline 9 & $\begin{array}{c}\text { Was the loss to follow-up after baseline } 20 \% \text { or less? Were those lost to follow-up accounted for in } \\
\text { the analysis? }\end{array}$ & 4 & 0 & 0 \\
\hline 10 & $\begin{array}{l}\text { Did the statistical methods examine changes in outcome measures from before to after the } \\
\text { intervention? Were statistical tests done that provided p values for the pre-to-post changes? }\end{array}$ & 4 & 0 & 0 \\
\hline 11 & $\begin{array}{l}\text { Were outcome measures of interest taken multiple times before the intervention and multiple times } \\
\text { after the intervention (i.e., did they use an interrupted time-series design)? }\end{array}$ & 0 & 0 & 4 \\
\hline 12 & $\begin{array}{l}\text { If the intervention was conducted at a group level (e.g., a whole hospital, a community, etc.) did the } \\
\text { statistical analysis consider the use of individual-level data to determine effects at the group level? }\end{array}$ & 0 & 0 & 4 \\
\hline
\end{tabular}

\subsection{Adverse Effects Associated with Mushroom Compounds Use as an Adjuvant on Conventional} Cancer Therapies

The role of active substances of mushrooms in the attenuation of adverse events of conventional cancer therapies remains unclear. In breast cancer patients it was observed that the oral administration of Lentinula eododes mycelia extract $[18,19]$ did not worsen or ameliorated the adverse events induced by the cancer conventional therapy. In addition, in breast cancer patients undergoing chemotherapy, Valadares et al. observed that the combined use of Agaricus sylvaticus extract and conventional therapy ameliorated the appetite and gastrointestinal symptoms such as diarrhea, constipation, nausea, and vomiting [20]. Similar results were observed by Chay et al. in a trial performed in patients with advanced hepatocellular cancer. According to this study, patients supplemented with Coriolus versicolor during chemotherapy had a decreased loss of appetite and pain when compared to the placebo group. Moreover, patients in the treatment group had lower average symptom scores for nausea, vomiting, pain, insomnia, constipation, and diarrhea [15].

The combined use of Agaricus blazei Murill Kyowa mushroom extracts in patients undergoing chemotherapy also decreased chemotherapy side effects such as loss of appetite and alopecia [24].

The use of Antrodia cinnamomea extracts as a chemotherapy adjuvant in patients with adenocarcinoma demonstrated that although gastrointestinal symptoms were more frequent, the intensity was lower compared to the untreated group [16].

Finally, in a preliminary study without a control group, Okuno et al. observed that during the first course of chemotherapy (without administration of Lentinula edodes mycelia extract) gastrointestinal cancer patients suffered from nausea and abdominal symptoms, and these adverse effects were not observed in the second course of chemotherapy (using Lentinula edodes mycelia extract combined with chemotherapy) [21]. 


\subsection{Hematological Parameters Associated with Mushroom Compounds/Extracts Use as an Adjuvant in Conventional Cancer Therapies}

According to our knowledge, the synergistic effects of mushrooms and cancer therapies in hematological parameters remains poorly described. In patients with breast cancer and advanced gastrointestinal cancer, no changes in hematological parameters were observed before and after the use of Lentinula eododes mycelia extracts [18,21]. Additionally, in breast cancer patients undergoing chemotherapy, Valadares et al. observed an increase in red blood cell count, hematocrit averages and corpuscular hemoglobin concentration [22]. In a study involving adenocarcinoma patients, it was observed that the synergistic effect of chemotherapy and Antrodia cinnamomea extracts caused a decrease in the number of platelets [16].

\subsection{Immunological Parameters Associated with Mushroom Compounds/Extracts Use as an Adjuvant in Conventional Cancer Therapies}

In breast cancer patients under chemotherapy, it was observed, through the evaluation of the ratio of IFN $\gamma / \mathrm{IL}-10$, that the administration of Lentinula eododes mycelia extracts can improve immune function [19] and prevent the reduction of natural killer (NK) cells activity [20]. Using a similar extract in advanced gastrointestinal cancer patients undergoing chemotherapy, Okuno et al [21] observed that the production of IFN- $\gamma$ by CD4 $4^{+} \mathrm{T}, \mathrm{CD} 8^{+} \mathrm{T}$ and $\mathrm{CD} 56^{+}$tend to increase.

According to Ahn et al., extracts of Agaricus blazei Murill can improve the activity of NK cells in gynecological cancer patients undergoing chemotherapy [24]. A clinical trial suggested that Coriolus versicolor extracts lead to a decrease in interleukin (IL) 17F and monocyte chemoattractant protein-1 (MCP-1) levels and to an increase in prolactin and TNF-related apoptosis-inducing ligand (TRAIL) R1 levels in patients with hepatocellular carcinoma [15].

\subsection{Quality of Life Associated with Mushroom Compounds/Extracts Use as an Adjuvant in Conventional Cancer Therapies}

Chay et al. evaluated the quality of life of patients with advanced hepatocellular carcinoma using the FACT HEP and EORTC QLQ-C30 questionnaires and concluded that the use of Coriolus versicolor extracts as an adjuvant in conventional therapy improved the quality of life of cancer patients. Patients treated with Coriolus versicolor experienced better physical, emotional, cognitive, and social functioning compared to the untreated group. The treated group patients also reported less pain compared to the untreated group [15]. After the application of an EORTC QLQ-30 modified questionnaire to cancer patients undergoing chemotherapy, Anh et al. observed that the use of Agaricus blazei Murill Kyowa extracts improved physical and mental conditions, in particular appetite, alopecia, nausea/vomiting, emotional conditions, and general body strength [24]. Suzuki et al. reported that the use of Lentinula eododes mycelia extract as adjuvant significantly increased QOL and vitality of breast cancer patients undergoing postoperative hormone therapy, between week 4 to week 8 of treatment [19]. In a study of patients with advanced adenocarcinoma cancer, Tsai et al. observed that only sleep was significantly improved with Antrodia Cinnamomea treatment combined with chemotherapy [16]. Zhao et al. observed that in breast cancer patients undergoing endocrine therapy, the subscales on the EORTC QLQ-C30 physical function, and global quality of life were improved for weeks after the treatment, in comparison to the untreated group. Fatigue, loss of appetite, and anxiety were also significantly improved in patients treated with the mushroom extracts in comparison to the control group [5].

\section{Discussion}

Despite the low quality of the included studies, the results of the present study suggest that mushrooms may have a synergistic effect on cancer patients undergoing conventional therapies, through improved quality of life and increased immune response. 
Adverse effects of conventional cancer therapy are one of the most important issues faced by cancer patients during their illness and significantly compromise their quality of life [25]. The majority of included studies that assessed quality of life (6/8) concluded that the use of mushroom treatments in combination with conventional therapies improves patients' quality of life, through improved physical [5,15], emotional [5,15], and cognitive, function $[5,15,23]$, and quality of sleep $[5,16]$. Decreased quality of sleep is frequently reported by cancer patients and contributes to an increased risk of depression [26-28]. One study reported that the nutritional status of patients was improved by treatment with Agaricus sylvaticus combined with chemotherapy [20]. Moreover, the consumption of Agraus brazei and Coriolus versicolor extracts combined with chemotherapy decreased vomiting and diarrhea in patients with gynecological [24] or hepatocellular cancer [15], respectively. Regarding adverse effects, although the majority of studies reported that the use of mushrooms can reduce the adverse effects of conventional therapy, only one study [15] out of a total of five studies $[5,15,16,20,23]$ that assessed adverse effects achieved significant values.

The immunomodulatory effects of medicinal mushrooms are well reported by in vitro studies and can potentially be used to minimize chemotherapeutic myelosuppression [29,30].

The included studies suggest that mushrooms can increase NK cells [23,24]. This observation was previously described in a Cochrane systematic review [31].

Cancer therapies can lead to leucopenia, granulocytopenia, thrombocytopenia, and anemia [32]. The included studies observed that the combined treatment of mushrooms and conventional therapies increased leukocytes, lymphocytes, and neutrophils [22,23].

The data obtained in this review suggest that mushroom products can enhance patients' tolerance to chemo and radiotherapy and reduce their toxicity and damaging side effects. Although the cell signaling pathway remains to be elucidated, in vitro studies suggested that mushrooms act as modulators of biochemical pathways associated with cell proliferation and transcription. The aberrant activation of this pathway was associated with the survival of cancer cells and resistance to chemotherapy and radiotherapy [33]. In future studies, new protocols to conduct clinical trials are needed to elucidate the possible active mechanisms and clinical benefits of these mushrooms in various types of cancer. Further investigations to evaluate the effects of mushroom treatments combined with conventional therapies in larger populations of cancer patients with a sample size large enough to detect clinical differences are needed to clarify whether mushrooms may play a role in the treatment of cancer.

The present study is not without some limitations. The search strategy was limited to the two main health research databases, and articles written in English, Spanish, and Portuguese. The included studies were heterogeneous in terms of population and sample size. As this review included studies regardless of the analysis of quality assessment and outcomes, bias may have been generated. Bias can be attributed to lack of randomization and concealment of interventions, sample size, and lack of similarity of participants at baseline which could affect outcomes, compromising possible scaling-up or extrapolation of interventions.

\section{Materials and Methods}

A literature search was conducted in September 2021 on the MEDLINE-PubMed and Cochrane database.

The search strategy was designed to identify relevant randomized controlled trials or clinical trials studies addressing the use of whole mushroom formulations as complementary therapy during conventional cancer treatment. Only articles written in English, Spanish, and Portuguese were included. 


\subsection{Outcome Measures}

Our primary outcome measure was the impact of mushroom adjuvant therapy on cancer patients undergoing a conventional therapy through the analysis of adverse effects, hematological and immunological parameters, and improvement of quality of life.

\subsection{Data Extraction}

Two researchers screened all titles and abstracts retrieved from the databases according to the inclusion criteria. To evaluate the eligibility of full-text articles, two researchers independently screened the full text of the articles. All discrepancies were resolved through discussion with the help of a third researcher.

Two researchers independently extracted data from the included studies. The data extracted from each article includes authors, publication year, study design, country, sample size, type of cancer, mushroom species name, outcome measures, and main results.

\subsection{Quality Assessment}

Two researchers independently evaluated the quality and susceptibility to the bias of the included studies using the "Quality Assessment of Controlled Intervention Studies" or "Quality Assessment Tool for Before-After (Pre-Post) Studies With No Control Group" tools (from the National Heart, Lung and Blood Institute), depending on the study design. All discrepancies were resolved through the discussion of a third or fourth researcher.

\section{Conclusions}

This study provides valuable data regarding the use of mushrooms as part of adjuvant therapy against many cancers; however, most of the included studies presented limitations that restrain the extrapolation of results to cancer pharmacotherapy. In order to obtain knowledge about the medicinal properties of mushrooms, studies designed with the aim of obtaining better evidence (existence of a control group and minimizing the risk of bias) are necessary, in order to clarify the beneficial effects of different species of mushrooms on different types of cancer.

Author Contributions: Conceptualization, A.I.P., M.M. and F.R.; methodology, A.I.P., M.M. and F.R.; validation, A.I.P., M.M. and F.R.; investigation, A.I.P., M.M. and F.R.; resources, F.R.; data curation, A.I.P. and M.M.; writing—original draft preparation, A.I.P. and M.M.; writing—review and editing, M.M. and F.R.; supervision, F.R. and M.M.; project administration, F.R.; funding acquisition, A.I.P. and F.R. All authors have read and agreed to the published version of the manuscript.

Funding: Participation of Ana I Plácido in this work was funded by the Grant CENTRO-04-3559-FSE000162, financed by the Operational Programme from the budget of the Central Region of Portugal, within the European Social Fund (ESF) component.

Institutional Review Board Statement: Not applicable.

Informed Consent Statement: Not applicable.

Data Availability Statement: Not applicable.

Acknowledgments: The authors would also like to thank the researchers Daniela Azevedo and Daniela Rodrigues, from the Polytechnic Institute of Guarda, for their collaboration in the collection of some data.

Conflicts of Interest: The authors declare no conflict of interest.

\section{References}

1. Ferlay, J.; Ervik, M.; Lam, F.; Colombet, M.; Mery, L.; Piñeros, M.; Znaor, A.; Soerjomataram, I.; Bray, F. Global Cancer Observatory: Cancer Today; International Agency for Research on Cancer: Lyon, France, 2020; Volume 68.

2. Sung, H.; Ferlay, J.; Siegel, R.L.; Laversanne, M.; Soerjomataram, I.; Jemal, A.; Bray, F. Global Cancer Statistics 2020: GLOBOCAN Estimates of Incidence and Mortality Worldwide for 36 Cancers in 185 Countries. CA Cancer J. Clin. 2021, 71, 209-249. [CrossRef] [PubMed] 
3. Ayeka, P.A. Potential of Mushroom Compounds as Immunomodulators in Cancer Immunotherapy: A Review. Evid.-Based Complementary Altern. Med. 2018, 2018, 1-9. [CrossRef] [PubMed]

4. Jeitler, M.; Michalsen, A.; Frings, D.; Hübner, M.; Fischer, M.; Koppold-Liebscher, D.A.; Murthy, V.; Kessler, C.S. Significance of Medicinal Mushrooms in Integrative Oncology: A Narrative Review. Front. Pharmacol. 2020, 11, 580656. [CrossRef] [PubMed]

5. Zhao, H.; Zhang, Q.; Zhao, L.; Huang, X.; Wang, J.; Kang, X. Spore Powder of Ganoderma Lucidum Improves Cancer-Related Fatigue in Breast Cancer Patients Undergoing Endocrine Therapy: A Pilot Clinical Trial. Evid.-Based Complement. Altern. Med. 2012, 2012, 1-8. [CrossRef]

6. Grant, S.J.; Hunter, J.; Seely, D.; Balneaves, L.G.; Rossi, E.; Bao, T. Integrative Oncology: International Perspectives. Integr. Cancer Ther. 2019, 18, 1534735418823266. [CrossRef] [PubMed]

7. Kozarski, M.; Klaus, A.; Jakovljevic, D.; Todorovic, N.; Vunduk, J.; Petrović, P.; Niksic, M.; Vrvic, M.M.; van Griensven, L. Antioxidants of Edible Mushrooms. Molecules 2015, 20, 19489-19525. [CrossRef] [PubMed]

8. Elsayed, E.A.; el Enshasy, H.; Wadaan, M.A.M.; Aziz, R. Mushrooms: A Potential Natural Source of Anti-Inflammatory Compounds for Medical Applications. Mediat. Inflamm. 2014, 2014, 1-15. [CrossRef] [PubMed]

9. Patel, D.K.; Dutta, S.D.; Ganguly, K.; Cho, S.J.; Lim, K.T. Mushroom-Derived Bioactive Molecules as Immunotherapeutic Agents: A Review. Molecules 2021, 26, 1359. [CrossRef] [PubMed]

10. Blagodatski, A.; Yatsunskaya, M.; Mikhailova, V.; Tiasto, V.; Kagansky, A.; Katanaev, V.L. Medicinal Mushrooms as an Attractive New Source of Natural Compounds for Future Cancer Therapy. Oncotarget 2018, 9, 29259-29274. [CrossRef] [PubMed]

11. Joseph, T.P.; Chanda, W.; Padhiar, A.A.; Batool, S.; LiQun, S.; Zhong, M.T.; Huang, M. A Preclinical Evaluation of the Antitumor Activities of Edible and Medicinal Mushrooms: A Molecular Insight. Integr. Cancer Ther. 2018, 17, 200-209. [CrossRef]

12. Figueiredo, L.; Régis, W.C.B. Medicinal Mushrooms in Adjuvant Cancer Therapies: An Approach to Anticancer Effects and Presumed Mechanisms of Action. Nutrire 2017, 42, 28. [CrossRef]

13. Zmitrovich, I.v.; Belova, N.v.; Balandaykin, M.E.; Bondartseva, M.A.; Wasser, S.P. Cancer without Pharmacological Illusions and a Niche for Mycotherapy (Review). Int. J. Med. Mushrooms 2019, 21, 105-119. [CrossRef] [PubMed]

14. Balakrishnan, B.; Liang, Q.; Fenix, K.; Tamang, B.; Hauben, E.; Ma, L.; Zhang, W. Combining the Anticancer and Immunomodulatory Effects of Astragalus and Shiitake as an Integrated Therapeutic Approach. Nutrients 2021, 13, 2564. [CrossRef] [PubMed]

15. Chay, W.Y.; Tham, C.K.; Toh, H.C.; Lim, H.Y.; Tan, C.K.; Lim, C.; Wang, W.W.; Choo, S.P. Coriolus Versicolor (Yunzhi) Use as Therapy in Advanced Hepatocellular Carcinoma Patients with Poor Liver Function or Who Are Unfit for Standard Therapy. J. Altern. Complement. Med. 2017, 23, 648-652. [CrossRef] [PubMed]

16. Tsai, M.Y.; Hung, Y.C.; Chen, Y.H.; Chen, Y.H.; Huang, Y.C.; Kao, C.W.; Su, Y.L.; Chiu, H.H.E.; Rau, K.M. A Preliminary Randomised Controlled Study of Short-Term Antrodia Cinnamomea Treatment Combined with Chemotherapy for Patients with Advanced Cancer. BMC Complement. Altern. Med. 2016, 16, 1-10. [CrossRef]

17. Tangen, J.M.; Tierens, A.; Caers, J.; Binsfeld, M.; Olstad, O.K.; Trøseid, A.M.S.; Wang, J.; Tjønnfjord, G.E.; Hetland, G. Immunomodulatory Effects of the Agaricus Blazei Murrill-Based Mushroom Extract Andosan in Patients with Multiple Myeloma Undergoing High Dose Chemotherapy and Autologous Stem Cell Transplantation: A Randomized, Double Blinded Clinical Study. BioMed Res. Int. 2015, 2015, 1-11. [CrossRef]

18. Nagashima, Y.; Maeda, N.; Yamamoto, S.; Yoshino, S.; Oka, M. Evaluation of Host Quality of Life and Immune Function in Breast Cancer Patients Treated with Combination of Adjuvant Chemotherapy and Oral Administration of Lentinula Edodes Mycelia Extract. OncoTargets Ther. 2013, 6, 853-859. [CrossRef]

19. Suzuki, N.; Takimoto, Y.; Suzuki, R.; Arai, T.; Uebaba, K.; Nakai, M.; Strong, J.M.; Tokuda, H. Efficacy of Oral Administration of Lentinula Eododes Mycelia Extract for Breast Cancer Patients Undergoing Postoperative Hormone Therapy. Asian Pac. J. Cancer Prev. 2013, 14, 3469-3472. [CrossRef]

20. Valadares, F.; Novaes, M.R.C.G.; Villafranca, R.C.; Menezes, M.D.C.; Reis, M.C.; Goncalves, D.R. Effect of Dietary Supplementation with Agaricus Sylvaticus Fungus on the Hematology and Immunology Systems of Breast Cancer Patients Undergoing Chemotherapy. Turk. Bull. Hyg. Exp. Biol. 2011, 68, 59-72. [CrossRef]

21. Okuno, K.; Uno, K. Efficacy of Orally Administered Lentinula Edodes Mycelia Extract for Advanced Gastrointestinal Cancer Patients Undergoing Cancer Chemotherapy: A Pilot Study. Asian Pac. J. Cancer Prev. 2011, 12, 1671-1674.

22. Valadares, F.; Novaes, M.R.C.G.; Cañete, R. Effect of Agaricus Sylvaticus Supplementation on Nutritional Status and Adverse Events of Chemotherapy of Breast Cancer: A Randomized, Placebo-Controlled, Double-Blind Clinical Trial. Indian J. Pharmacol. 2013, 45, 217-222. [CrossRef] [PubMed]

23. Yamaguchi, Y.; Miyahara, E.; Hihara, J. Efficacy and Safety of Orally Administered Lentinula Edodes Mycelia Extract for Patients Undergoing Cancer Chemotherapy: A Pilot Study. Am. J. Chin. Med. 2011, 39, 451-459. [CrossRef] [PubMed]

24. Ahn, W.S.; Kim, D.J.; Chae, G.T.; Lee, J.M.; Bae, S.M.; Sin, J.I.; Kim, Y.W.; Namkoong, S.E.; Lee, I.P. Natural Killer Cell Activity and Quality of Life Were Improved by Consumption of a Mushroom Extract, Agaricus Blazei Murill Kyowa, in Gynecological Cancer Patients Undergoing Chemotherapy. Int. J. Gynecol. Cancer 2004, 14, 589-594. [CrossRef] [PubMed]

25. Baldo, P.; Fornasier, G.; Ciolfi, L.; Sartor, I.; Francescon, S. Pharmacovigilance in Oncology. Int. J. Clin. Pharm. 2018, 40, 832-841. [CrossRef]

26. Weng, Y.P.; Hong, R.M.; Chen, V.C.H.; Tsai, C.J.; Yeh, D.C.; Fang, Y.H. Sleep Quality and Related Factors in Patients with Breast Cancer: A Cross-Sectional Study in Taiwan. Cancer Manag. Res. 2021, 13, 4725-4733. [CrossRef] 
27. Otte, J.L.; Carpenter, J.S.; Manchanda, S.; Rand, K.L.; Skaar, T.C.; Weaver, M.; Chernyak, Y.; Zhong, X.; Igega, C.; Landis, C. Systematic Review of Sleep Disorders in Cancer Patients: Can the Prevalence of Sleep Disorders Be Ascertained? Cancer Med. 2015, 4, 183-200. [CrossRef]

28. Ravasco, P. Nutrition in Cancer Patients. J. Clin. Med. 2019, 8, 1211. [CrossRef]

29. El Enshasy, H.A.; Hatti-Kaul, R. Mushroom immunomodulators: Unique molecules with unlimited applications. Trends Biotechnol. 2013, 31, 668-677. [CrossRef]

30. Guggenheim, A.G.; Wright, K.M.; Zwickey, H.L. Immune modulation from five major mushrooms: Application to integrative oncology. Integr. Med. 2014, 13, 32-44.

31. Jin, X.; Ruiz Beguerie, J.; Sze, D.M.Y.; Chan, G.C.F. Ganoderma Lucidum (Reishi Mushroom) for Cancer Treatment. Cochrane Database Syst. Rev. 2016, 2016, CD007731. [CrossRef]

32. Chen, L.; Kong, X.; Yan, C.; Fang, Y.; Wang, J. The Research Progress on the Prognostic Value of the Common Hematological Parameters in Peripheral Venous Blood in Breast Cancer. OncoTargets Ther. 2020, 13, 1397-1412. [CrossRef] [PubMed]

33. Neergheen, V.S.; Hip Kam, A.; Pem, Y.; Ramsaha, S.; Bahorun, T. Regulation of Cancer Cell Signaling Pathways as Key Events for Therapeutic Relevance of Edible and Medicinal Mushrooms. Semin. Cancer Biol. 2020, in press. [CrossRef] [PubMed] 